\title{
EFFECT OF TEMPERATURE ON THE DEVELOPMENT AND VIABILITY OF Gryon gallardoi (BRETHES) (HYMENOPTERA: SCELIONIDAE) PARASITIZING Spartocera dentiventris (BERG) (HEMIPTERA: COREIDAE) EGGS
}

\author{
'CANTO-SILVA, C. R., ${ }^{1}$ ROMANOWSKI, H. P. ${ }^{1,2}$ and REDAELLI, L. R. \\ ${ }^{1}$ PPG Biologia Animal, UFRGS, Av. Bento Gonçalves, 9500, CEP 91501-970, Porto Alegre, RS \\ ${ }^{2}$ Departamento de Fitossanidade, UFRGS, Av. Bento Gonçalves, 7712, CEP 91540-000, Porto Alegre, RS \\ Correspondence to: Célson Roberto Canto Silva, Rua Euclides da Cunha, 362, Bairro Jardim América, \\ CEP 93032160, São Leopoldo, RS, e-mail: cantosilva@ig.com.br \\ Received June 2, 2003 - Accepted October 16, 2003 - Distributed August 31, 2005
}

(With 2 figures)

\begin{abstract}
The development and viability of Gryon gallardoi (Brethes) (Hym.: Scelionidae) in Spartocera dentiventris (Berg) (Hem.: Coreidae) eggs were studied under four temperatures: 15, 20, 25, and $30 \pm 1^{\circ} \mathrm{C}$, with a 12 -h photophase. No parasitoid developed at $15^{\circ} \mathrm{C}$. Otherwise, viability reached $98.8 \%$ without varying significantly over the temperature range tested. The duration of development for males and females was inversely proportional to the temperature increase, varying respectively from $46.2 \pm 0.13$ and $47.1 \pm$ 0.11 days $\left(20^{\circ} \mathrm{C}\right)$ to $13.3 \pm 0.07$ and $13.4 \pm 0.06$ days $\left(30^{\circ} \mathrm{C}\right)$. Males developed faster than females. The values estimated for the lowest thermic thresholds of development and the thermic constants were $15.5^{\circ} \mathrm{C}$ and 185.19 DD for males and $15.6^{\circ} \mathrm{C}$ and 192.31 DD for females, respectively. Given the average weather conditions in Porto Alegre, RS (30 $01^{\prime}$ 'S and $\left.51^{\circ} 13^{\prime} \mathrm{W}\right)$, Brazil, G. gallardoi could annually produce 8.54 and 8.07 generations of males and females, respectively. The low rates of parasitism observed in the field during the first generation of its host may be due to the small number of $G$. gallardoi generations in this period.
\end{abstract}

Key words: insecta, tobacco, gray-tobacco-bug, parasitoid, thermal requirements.

\section{RESUMO}

O efeito da temperatura no desenvolvimento e na viabilidade de Gryon gallardoi (Brethes) (hym.: scelionidae) parasitando ovos de Spartocera dentiventris (Berg) (Hem.: coreidae)

Foram avaliados o desenvolvimento e a viabilidade de Gryon gallardoi (Brethes) (Hym.: Scelionidae) em ovos de Spartocera dentiventris (Berg) (Hem.: Coreidae) sob 4 temperaturas constantes: 15, 20, 25 e $30 \pm 1^{\circ} \mathrm{C}$ e fotofase de $12 \mathrm{~h}$. Nenhum parasitóide desenvolveu-se à $15^{\circ} \mathrm{C}$. A viabilidade dos parasitóides na faixa de 20 a $30^{\circ} \mathrm{C}$ não diferiu significativamente, alcançando 98,8\%. O tempo de desenvolvimento ovoadulto de machos e fêmeas foi inversamente proporcional ao aumento da temperatura, variando, respectivamente, de 46,2 $\pm 0,13$ e 47,1 $\pm 0,11$ dias $\left(20^{\circ} \mathrm{C}\right)$ a 13,3 $\pm 0,07$ e 13,4 $\pm 0,06$ dias $\left(30^{\circ} \mathrm{C}\right)$. Os machos apresentaram período médio de desenvolvimento significativamente mais curto que as fêmeas. Os valores estimados para o limite térmico inferior de desenvolvimento e para a constante térmica foram $15,5^{\circ} \mathrm{C}$ e $185,19 \mathrm{GD}$ para machos e $15,6^{\circ} \mathrm{C}$ e 192,31 GD para fêmeas. Dadas as médias climáticas de Porto Alegre (30 $01^{\prime}$ S e $51^{\circ} 13^{\prime}$ O), RS, Brasil, G. gallardoi poderia apresentar 8,54 e 8,07 gerações anuais de machos e fêmeas, respectivamente. Sugere-se que as baixas taxas de parasitismo observadas em campo na primeira geração do percevejo resultem do número reduzido de gerações do parasitóide nesse período.

Palavras-chave: insecta, fumo, percevejo-cinzento-do-fumo, parasitóide, exigências térmicas. 


\section{INTRODUTION}

The gray-tobacco-bug, Spartocera dentiventris (Berg) (Hemiptera: Coreidae), is a species potentially harmful to tobacco crops in Rio Grande do Sul, since it may cause leaves to wither and curl up (Parseval, 1937; Costa, 1941; Schaefer \& Panizzi, 2000). In spite of their high reproductive potential (Caldas et al., 1999), populations of this bug under field conditions are drastically reduced by various environmental factors (Canto-Silva, 1999). Among these, parasitoid action causes significant loss in the egg stage. Gryon gallardoi (Brethes) (Hymenoptera: Scelionidae) is the main parasitoid species (Santos et al., 2001) and was first reported for Brazil in eggs of Spartocera lativentris, a coreid which attacks various cultivated and non-cultivated plants (Loiacono, 1980; Becker \& Prato, 1982). The species is also cited as a parasitoid of eggs of the coreid Leptoglossus zonatus (Dallas), a significant pest in citrus and corn in southeast Brazil (DeSouza \& Amaral-Filho, 1999). Despite the importance of these crops, little is known about $G$. gallardoi. Studies on its biology and ecology are fundamental in evaluating the potential that this species may have as a biological control agent.

One study showed that two generations of $S$. dentiventris develop during the tobacco cycle: the first from the end of August to December, and the second from the end of December to February (Jesus \& Romanowski, 2001). Parasitism occurs in eggs of both generations, but the rate is low during the first generation (Canto-Silva, 1999). There are many factors that may determine the levels of parasitism observed in the field; however, as emphasized by Doutt et al. (1976), settlement of entomophagus insects is largely influenced by the effect of temperature on developing individuals. Thus, the understanding of interaction dynamics in the field involves evaluating thermic requirements by the developing organisms. This knowledge is a fundamental element in building populational models (Powell et al., 1981).

Thermic requirements have been determined for a number of Scelionidae parasitoids (James \& Warren, 1991; Cividanes \& Figueiredo, 1996; Torres et al., 1997). However, information of this nature is still rare for the genus Gryon (Nechols et al., 1989), and non-existent for G. gallardoi. Thus, this study was proposed to investigate the viability and development time of G. gallardoi from eggs of $S$. dentiventris under various constant temperatures to estimate the lower thermic limit for development $\left(\mathrm{t}_{\mathrm{o}}\right)$, the thermic constant $(\mathrm{K})$, and the number of generations monthly and yearly possible for this species under the temperature conditions prevailing in Porto Alegre, RS, Brazil.

\section{MATERIAL AND METHODS}

The present study was carried out in the Departamento de Fitossanidade, Faculdade de Agronomia, Universidade Federal do Rio Grande do Sul (UFRGS), Porto Alegre $\left(30^{\circ} 01^{\prime} \mathrm{S}\right.$ and $\left.51^{\circ} 13^{\prime} \mathrm{W}\right), \mathrm{RS}$, Brazil, from November 2000 to February 2001. G. gallardoi individuals were obtained from $S$. dentiventris-parasitized eggs collected from tobacco areas in Venâncio Aires (29 $60^{\prime} \mathrm{S}$ and $\left.52^{\circ} 19^{\prime} \mathrm{W}\right), \mathrm{RS}$, where the species occurs abundantly.

After emergence and identification of the parasitoids, they were reared in the laboratory in $500 \mathrm{ml}$ transparent plastic bottles, containing $S$. dentiventris eggs, and sealed with cotton. These bottles were kept horizontally at $25 \pm 1^{\circ} \mathrm{C}$, with a 12-hour photophase. The parasitoids were fed ad libitum on a $10 \%$ aqueous honey solution daily.

Non-parasited $S$. dentiventris eggs were obtained from an experimental crop grown close to the laboratory. $S$. dentiventris females were kept in the tobacco plants within voile cages that impeded access by parasitoids. Groups of less than 24-hourold eggs were collected daily together with the part of the plant (leaf, stem) in which they were laid. These were then placed in the breeding bottles and exposed to parasites at $25 \pm 1^{\circ} \mathrm{C}$ for ca. 15 hours. After this period, the eggs were transferred to Petri dishes and reared at one of the following temperatures: 15, 20, 25 , and $30 \pm 1^{\circ} \mathrm{C}$, with a $12 \mathrm{~h}$ photophase. Parasitized eggs differed from eggs with normal bug embrionic development (Caldas et al., 1999), by becoming darker after a few days (Santos et al., 2001). Parasitoid viability was only estimated from eggs old enough to evidence parasitism. Therefore, replications amounted to about 340 parasited eggs for each temperature. Parasitoid emergence was checked daily and individuals were sexed based on antennae dimorphism (Loiacono, 1980).

The lower thermic limit of development $\left(t_{0}\right)$ and the thermic constant $(\mathrm{K})$ were estimated by the hyperbole method (Haddad \& Parra, 1984). The possible number of generations per month was calculated by taking the estimates for thermic 
requiriments $\left(\mathrm{t}_{\mathrm{o}}\right.$ e $\mathrm{K}$ ) and the total of degrees-day (DD) during the considered period, using the formula adapted from Torres et al. (1997): $\mathrm{NG}=\left[\mathrm{T}\left(\mathrm{t}_{\mathrm{c}}-\right.\right.$ $\left.\left.\mathrm{t}_{\mathrm{o}}\right)\right] / \mathrm{K}$, where $\mathrm{NG}=$ number of generations, $\mathrm{T}=$ period considered ( 30 days), and $t_{c}=$ monthly average temperatures from 1991 to 2000 in Porto Alegre, RS. The number of generations per year was obtained by adding the estimates per month.

Differences in the observed length of development for males and females were assessed by ANOVA and the Tukey test. The viability at different temperatures was compared by goodness of fit to the chi-square distribution.

\section{RESULTS AND DISCUSSION}

No parasitoid developed at $15^{\circ} \mathrm{C}$. Eggs presumably parasitized were kept at this temperature for as long as 90 days and neither darkening in color nor eclosion of $S$. dentiventris nymphs was ever observed. The viability of the development of $G$. gallardoi egg-adults in a range from 20 to $30^{\circ} \mathrm{C}$ was virtually total, reaching up to $98.8 \%$ at $20^{\circ} \mathrm{C}$ (Table 1). Only a very slight decrease was observed with the increase of temperature, but this was not significant $\left(\chi^{2}=4.1127 ; \mathrm{df}=2 ; \mathrm{p}=0.1279\right.$; Table 1$)$. Similar results were obtained by Corrêa-Ferreira \& Moscardi (1994), who recorded approximately $100 \%$ viability for Scelionidae Trissolcus basalis (Woll.) parasitizing eggs of the pentatomid Nezara viridula (L.) at temperatures from 18 to $30^{\circ} \mathrm{C}$ in southern Brazil and by Torres et al. (1997) who reported approximately 90\% viability for the scelionids Trissolcus brochymenae (Ashmead) and Telenomus podisi Ashmead parasitizing eggs of the pentatomid Podisus nigrispinus (Dallas) in Minas Gerais, Brazil, in ranges from 17 to $32^{\circ} \mathrm{C}$ and $20^{\circ}$ and $28^{\circ} \mathrm{C}$, respectively. On the other hand, in a study about parasitoids of the coreid Anasa tristis DeGeer in the central part of the USA, Nechols et al. (1989) observed a viability of only $36 \%$ for Gryon pennsylvanicum (Ashmead) at $18.3^{\circ} \mathrm{C}$ and over $80 \%$ in the range from 21.1 to $29.4^{\circ} \mathrm{C}$. In the southeastern USA, Yergan (1980) reported no male and only $43.5 \%$ of the females of $T$. podisi parasitizing eggs of the pentatomidae Podisus maculiventris (Say) emerged at $15.5^{\circ} \mathrm{C}$.

The length of development of G. gallardoi in $S$. dentiventris eggs significantly diminished with temperature increase ( $p>0.05$; Fig. 1$)$. The average length of development from egg to adult for males and females varied respectively from $13.3 \pm 0.07$ and $13.4 \pm 0.06$ days $\left(30^{\circ} \mathrm{C}\right)$ to $46.2 \pm 0.13$ and $47.1 \pm 0.11$ days $\left(20^{\circ} \mathrm{C}\right)$ (Table 1$)$. Females bred at $25^{\circ} \mathrm{C}$ presented an average development period 5.7 days longer than that at $30^{\circ} \mathrm{C}$, while a decrease of $5^{\circ} \mathrm{C}$ more in temperature $\left(20^{\circ} \mathrm{C}\right)$ resulted in an average development period of about 28 days longer (Table 1). There was a sharp decrease in the rate of development at temperatures below $25^{\circ} \mathrm{C}$ (Fig. 1). Males presented development periods significantly shorter than those of females at all temperatures above $15^{\circ} \mathrm{C}(\mathrm{p}>0.05$; Table 1$)$.

TABLE 1

Mean development length (days) and viability (\%) of Gryon gallardoi on Spartocera dentiventris egg at different temperatures.

\begin{tabular}{|c|c|c|c|}
\hline \multirow{2}{*}{ Temperature $\left({ }^{\mathbf{0}} \mathbf{C}\right)$} & \multicolumn{2}{|c|}{ Mean length of development (days) \pm S.E. } & \multicolumn{2}{c|}{$\begin{array}{c}\text { viability } \\
\text { (n) }\end{array}$} \\
\cline { 2 - 4 } & $\begin{array}{c}\text { Male } \\
(\mathbf{n})\end{array}$ & $\begin{array}{c}\text { Female } \\
(\mathbf{n})\end{array}$ & \multicolumn{2}{c|}{0.0} \\
\hline \multirow{2}{*}{15} & - & - & $(300)$ \\
\hline \multirow{2}{*}{20} & $46.2 \pm 0.13 \mathrm{Aa}$ & $47.1 \pm 0.11 \mathrm{Ab}$ & 98.81 \\
& $(190)$ & $(146)$ & $(340)$ \\
\hline \multirow{2}{*}{25} & $18.6 \pm 0.07 \mathrm{Ba}$ & $19.1 \pm 0.05 \mathrm{Bb}$ & 97.41 \\
& $(101)$ & $(231)$ & $(341)$ \\
\hline \multirow{2}{*}{30} & $13.3 \pm 0.07 \mathrm{Ca}$ & $13.4 \pm 0.06 \mathrm{Cb}$ & 96.41 \\
& $(110)$ & $(214)$ & $(336)$ \\
\hline
\end{tabular}

Values followed by same capital letter within columns and lower case within lines are not significantly different ( $\mathrm{p}<0.05$; Tukey test). ${ }^{1}$ Values are not significantly different $\left(\chi^{2}=4.1127 ; \mathrm{df}=2 ; \mathrm{p}=0.1279\right)$. 


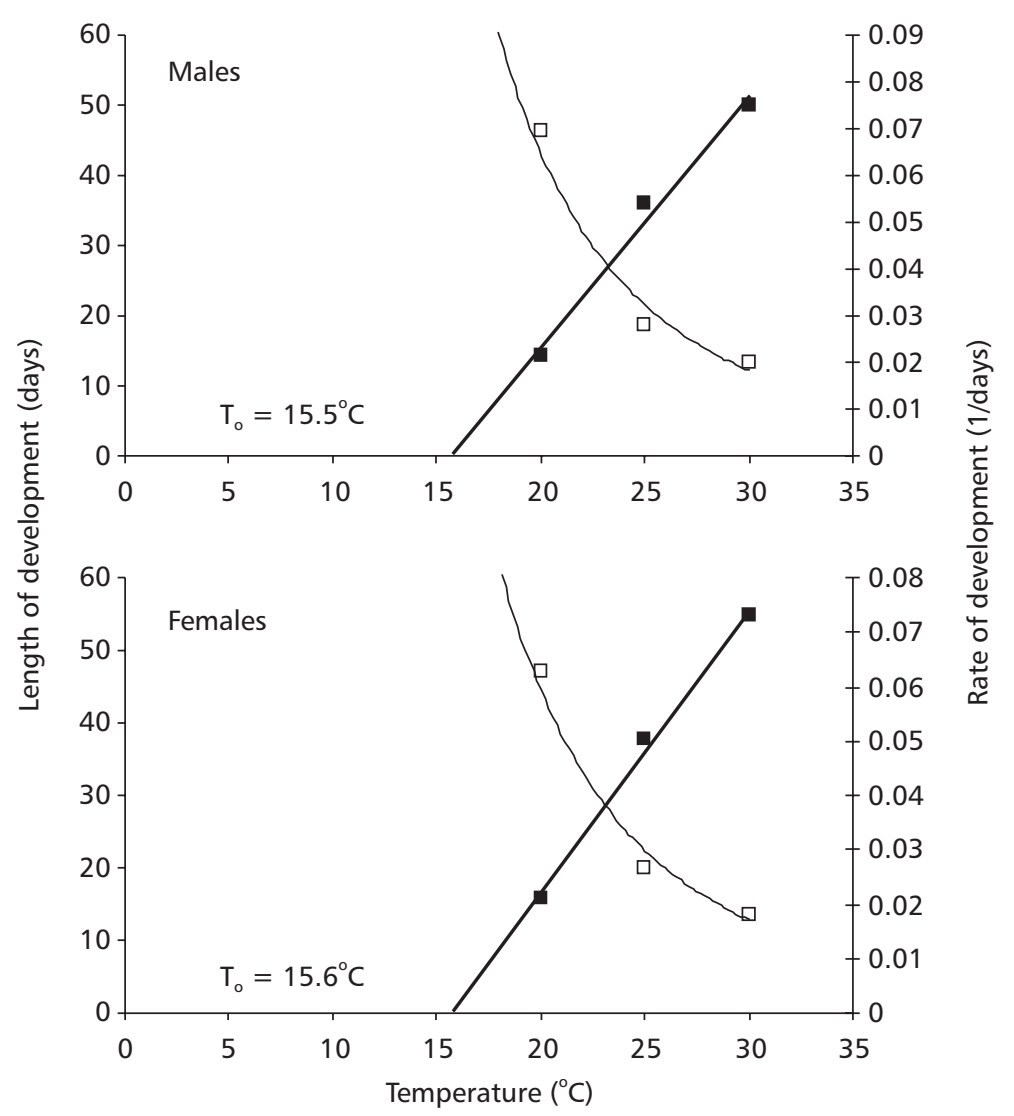

Fig. 1 - Relationship between length of development (open squares), developmental rate (black squares), and temperature for immature stage of Gryon gallardoi parasitizing Spartocera dentiventris eggs. $\left(\mathrm{T}_{\mathrm{o}}=\right.$ lower threshold temperature.)

More than $98 \%$ of the decrease observed for male and female rates of development could be explained by the temperature increase (Table 2). The lower thermic thresholds for development and the thermic constants estimated were $15.5^{\circ} \mathrm{C}$ and 185.19 DD for males and $15.6^{\circ} \mathrm{C}$ and 192.31 DD for females respectively (Table 2 ). The fact that parasitized eggs bred at $15^{\circ} \mathrm{C}$ did not change color indicates a halt in the initial development phase, corroborating the estimated $t_{0}$ values.

The estimated lower thermic thresholds of development for G. gallardoi may be considered high when compared to those reported for other Scelionidae species. G. pennsylvanicum in A. tristis eggs in the northeastern United States (Nechols et al., 1989) and Trissolcus oenone Dodd in the Biprorulus bibax Breddin in southern Australia (James \& Warren, 1991) both showed a value of $12.4^{\circ} \mathrm{C}$ as the basal temperature for development. These values are similar to that of $15^{\circ} \mathrm{C}$ obtained for scelionids Telenomus chloropus Thomson and T. basalis em N. viridula in Louisiana (USA) and closely approximate the values of $14.1^{\circ} \mathrm{C}$ and $13.2^{\circ} \mathrm{C}$ obtained by Cividanes \& Figueiredo (1996) for $T$. brochymenae and $T$. podisi, respectively, in Piezodorus guildinii (West.) eggs in southeastern Brazil and $14.1^{\circ} \mathrm{C}$ obtained for Telonomus reynoldsi Gordh \& Coker in Geocoris punctipes (Say) (Heteroptera; Lygaeidae) eggs in the southern USA (Cave \& Gaylor, 1988). 
TABLE 2

Lower threshold temperature, thermal requirement and regression equation of Gryon gallardoi male and female development parasitizing Spartocera dentiventris egg.

\begin{tabular}{|c|c|c|c|c|c|}
\hline Sex & $\begin{array}{c}\text { Lower threshold } \\
\text { temperature } \\
\left({ }^{\mathbf{0}} \mathbf{C}\right)\end{array}$ & $\begin{array}{c}\text { Thermal } \\
\text { requirement } \\
(\text { DD) }\end{array}$ & Regression equation & $\mathbf{r 2}$ & $\mathbf{p}$ \\
\hline Male & 15.5 & 185.19 & $1 / \mathrm{D}=-0.0837+0.0054 \mathrm{~T}$ & 0.987 & 0.07 \\
\hline Female & 15.6 & 192.31 & $1 / \mathrm{D}=-0.0812+0.0052 \mathrm{~T}$ & 0.995 & 0.04 \\
\hline
\end{tabular}

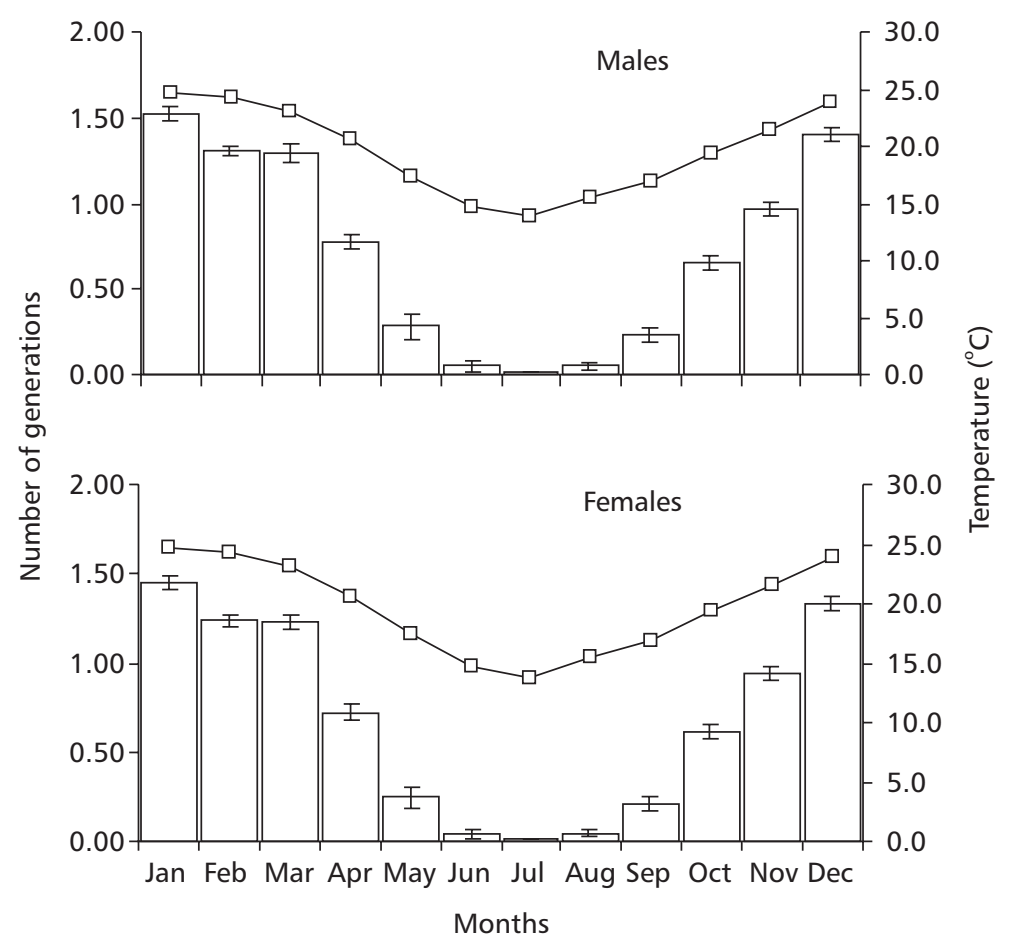

Fig. 2 - Estimated number of generations per month (blocks) of Gryon gallardoi parasitizing Spartocera dentiventris eggs and monthly average temperatures (line) in Porto Alegre (30 $01^{\prime} \mathrm{S}$ and $\left.51^{\circ} 13^{\prime} \mathrm{W}\right)$, RS, Brazil.

The values calculated for the thermic constant (K) for G. gallardoi development resulted in values close to those estimated for T. brochymenae and T. podisi, in P. guildinii: 199.1 and $150.7 \mathrm{DD}$, respectively (Cividanes \& Figueiredo, 1996). In studies made in the Brazilian southwest for the same parasitoid species, Torres et al. (1997) also obtained similar values for P. nigrispinus: 189.2 and 214.7
DD, and 177.6 and 205.3 DD for males and females, respectively. However, they are below that obtained for G. pennsylvanicum: $281 \mathrm{DD}$ (Nechols et al., 1989). The values of $t_{o}$ and $K$ associated with the high survival rate observed for G. gallardoi at all temperatures suggest that the species may be adapted to high temperature environments, typical of tropical regions. 
Extrapolating from the average temperatures per month in Porto Alegre over the last 10 years, G. gallardoi could develop 8.54 and 8.07 annual generations of males and females, respectively. The possible number of generations per month estimated for both sexes is presented in Fig. 2. This figure indicates that in winter (May to July) temperature can be a limiting factor in parasitoid development, which suggests a diapause strategy in this species. Considering the initial infestation period of tobacco by $S$. dentiventris (from August on), only in November the temperatures would be high enough for the first generation of parasitoids to develop, thus explaining the low rates of parasitism observed in the field in this bug's first generation (CantoSilva, 1999). On the other hand, the estimated number of parasitoid generations (approximately 7) during the tobacco cycle is much higher than that observed for the bug (2 generations), which would increase parasitism efficiency. It must be emphasized that following the end of the tobacco cycle, which occurs in March, prevailing temperature conditions do not as yet limit the development of additional generations of bugs. This suggests that other plants might be used to favor continuity in the hostparasitoid interaction.

In conclusion, G. gallardoi seems to have great potential for controlling populations of $S$. dentiventris because of the great number of generations it can develop per season as well as its high viability at the various temperatures studied. However, its susceptibility to low temperatures (high threshold of lower development) may be a limiting factor in cold-climate regions.

Acknowledgements - The authors thank the Departamento de Fitossanidade, Faculdade de Agronomia, Universidade Federal do Rio Grande do Sul for allowing the use of the facilities in which this study was carried out. We are also grateful to the $8^{\circ}$ Distrito de Meteorologia, Porto Alegre, for weather data. Thanks are also expressed to Dr. Beatriz S. Corrêa-Ferreira for information and bibliography provided.

\section{REFERENCES}

BECKER, M. \& PRATO, M. D., 1982, Natality and natural mortality of Spartocera lativentris Stal, 1870 (Heteroptera: Coreidae) in the egg stage. An. Soc. Entomol. Brasil, 11: 269-281.
CALDAS, B-H. C., REDAELLI, L. R. \& DIEFENBACH, L. M. G., 1999, Parâmetros reprodutivos de Corecoris dentiventris Berg (Hemiptera, Coreidae) em cultura de fumo (Nicotiana tabacum). An. Soc. Entomol. Brasil, 28(4): 595-600.

CANTO-SILVA, C. R., 1999, Aspectos da dinâmica populacional e distribuição espacial de Corecoris dentiventris Berg, 1884 (Heteroptera; Coreidae) em cultivo experimental de Nicotiana tabacum (Solanaceae). Dissertação de Mestrado - UFRGS Porto Alegre. 148p.

CAVE, R. D. \& GAYLOR, M. J., 1988, Influence of temperature and humidity on development and survival of Telonomus reynoldsi (Hymenoptera: Scelionidae) parasitizing Geocoris punctipes (Heteroptera: Lygaeidae) eggs. Ann. Entomol. Soc. Am., 81(2): 278-285.

CIVIDANES, F. J. \& FIGUEIREDO, J., 1996, Desenvolvimento e emergência de Trissolcus brochymenae (Ashmead) e Telonomus podisi (Hym.; Scelionidae) em diferentes temperaturas. An. Soc. Entomol. Brasil 25(2): 207-211.

CORRÊA-FERREIRA, B. S. \& MOSCARDI, F., 1994, Temperature effect on the biology and reproductive performance of the egg parasitoid Trissolcus basalis (Woll.) An. Soc. Entomol. Brasil, 23(3): 399-408.

COSTA, R. G., 1941, Pragas de plantas cultivadas no Rio Grande do Sul. Porto Alegre, Secretaria da Agricultura, 136.

DE-SOUZA, C. E. P. \& AMARAL-FILHO, B. F., 1999, Ocorrência natural de parasitóides de Leptoglossus zonatus (Dallas) (Heteroptera: Coreidae). An. Soc. Entomol. Brasil, 28(4): 757-759.

DOUTT, R. L., ANNECKE, D. P. \& TREMBLAY, E., 1976, Biology and host relationships in parasitoids. In: C. B. Huffaker \& P. S. Messenger (eds.). Theory and practice of biological control. Academic Press, New York.

HADDAD, M. L. \& PARRA, J. R. P., 1984, Métodos para estimar os limites térmicos e a faixa de desenvolvimento das diferentes fases do ciclo evolutivo dos insetos. Fundação de Estudos Agrários "Luiz de Queiroz", Ser. Agric. e Des., Piracicaba, 12p.

JAMES, D. G. \& WARREN, G. N., 1991, Effect of temperature on development, survival, longevity and fecundity of Trissolcus oenone Dodd (Hymenoptera: Scelionidae). J. Aust. Ent. Soc., 30: 303-306.

JESUS, C. R. \& ROMANOWSKI, H. P., 2001, Population dynamics of Corecoris dentiventris Berg. 1884 (Hemiptera: Coreidae) at an experimental tobacco crop in Porto Alegre, RS - Brazil. Biotemas, 14(2): 47-60.

LOIACONO, M. S., 1980, Nota sobre tres Scelionidos parasitoides de hemipteros de la República argentina y Brasil (Hymenoptera-proctotrupoidea). Rev. Soc. Ent. Argentina, 39(3-4): 173-178.

NECHOLS, J. R., TRACY, J. L. \& VOGT, E. A., 1989, Comparative studies of indigenous egg parasitoids (Hymenoptera: Scelionidae; Encyrtidae) of the Squash Bug, Anasa tristis (Hemiptera: Coreidae). J. Kansas Entom. Soc., 62(2): 177-188. 
ORR, D. B., BOETHEL, D. J. \& JONES, W. A., 1985, Development and emergence of Telonomus chloropus and Trissolcus basalis (Hymenoptera: scelionidae) at various temperatures and relative humidities. Ann. Entomol. Soc. Am., 78(5): 615-619.

PARSEVAL, M. von., 1937, As pragas do fumo do Rio Grande do Sul. Chácaras e Quintais, 56: 489-494.

POWELL, J. E., SHEPARD, M. \& SULLIVAN, M. J., 1981, Use of heating degree day and physiological day equations for predicting development of the parasitoid Trissolcus basalis. Environ. Entomol., 10: 1008-1011.

SANTOS, R. S. S., REDAELLI, L. R. \& DIEFENBACH, L. M. G., 2001, Ocorrência de parasitismo em ovos de Spartocera dentiventris (Berg) (Hemiptera: Coreidae) em cultura de fumo. Neotropical Entomology, 30(4): 731-733.
SCHAEFER, C. W. \& PANIZZI, A. R., 2000, Heteroptera of economic importance. CRC Press, Boca Raton, Florida, USA, $828 \mathrm{p}$.

TORRES, J. B., PRATISSOLI, D. \& ZANUNCIO, J. C., 1997, Exigências térmicas e potencial de desenvolvimento dos parasitóides Telenomus podise Ashmead e Trissolcus Brochymenae (Ashmead) em ovos do percevejo predador Podisus nigrispinus (Dallas). An. Soc. Entomol. Brasil, 26(3): 445-453.

YERGAN, K.V., 1980, Effects of temperature on developmental rate of Telonomus podisi (Hymenoptera: Scelionidae). Ann. Entomol. Soc. Am., 73(3): 339-342. 